\title{
Levels and stages of artificial defoliation in the agronomic performance of the cassava crop
}

\author{
Martios Ecco' , Antônio Carlos Torres da Costa², José Barbosa Duarte Júnior², Augustinho Borsoi, \\ Milciades Ariel Melgarejo Arrúa ${ }^{4}$
}

${ }^{1}$ Department of the course of Agronomy of the Pontifical Catholic University of Paraná, Toledo campus, Avenida da União, 500, 85902-532, Toledo, Paraná, Brazil, '²Department of the Agronomy course of the State University of Western Paraná, Marechal Cândido Rondon campus, Pernambuco Street, 91, 85960-000, Paraná, Brazil, ${ }^{3}$ Department of the Agronomy course of Assis Gurgacz College, Cascavel campus, Avenida das Torres, 500, 85806-095, Paraná, Brazil, ' ${ }^{4}$ Department of the Agronomy course at the National University of Canindeyú, Salto del Guairá campus, Paraguay

\section{A B S T R A C T}

The cassava crop is susceptible to foliar loss due to several pests, which interfere with the photosynthetic rate, causing large losses mainly to its organ of interest, which are the roots. The objective of this study was to evaluate the agronomic performance of cassava crop following different levels of artificial defoliation at different stages of development. The experiment was conducted in Guaíra-PR, using a randomized block design in a $5 \times 5$ factorial scheme, with five levels of defoliation in five developmental stages. The levels consisted of $0,25,50,75$, and $100 \%$ defoliation, and the stages were 45, 90, 135, 180, and 225 days after planting (DAP). The responses of the variable height and plant diameter were inversely proportional according to the interaction of the factors levels and times of defoliation, especially when $100 \%$ defoliation was performed at 90 DAP. For root weight, the greatest level of defoliation at 132 DAP resulted in a low yield, whereas for starch deposition in the roots, only the levels had a significant effect for reduction, presenting a linear decreasing effect according to an increase in defoliation. In conclusion, high levels of defoliation between 122 and 132 DAP resulted in greater damage to the root mass; these high defoliation levels independent of the defoliation stage caused the largest losses in the amount of stored starch.

Keywords: Erinnyis ello; Leaf; Manihot esculenta

\section{INTRODUCTION}

Cassava (Manihot esculenta L. Crantz) is a plant of multiple uses and is the main source of carbohydrate for millions of people worldwide (Alves, 2006). The roots are the main plant part of interest and are highly dependent on the leaves for the production of photoassimilates, which are converted into sugars and then stored in the roots as starch.

Many pests attack the crop and inhibit the transport of nutrients or reduce the sprouting of planting material; however, the main damage is the loss of leaf area, reducing the active photosynthetic rate of the plant, which will reduce the translocation of photoassimilates to the roots, resulting in a fall in production (Souza et al., 2013).

Studies have been performed with different crops to adequately measure and determine safe parameters in establishing the level of economic damage of a particular pest or climatic conditions especially that associated with artificial defoliation (Lima Junior et al., 2010; Scarpare Filho et al., 2010).

Artificial defoliation is used to simulate crop damage, such as the frequent attacks of defoliating pests or hail rain. Therefore, it is possible to measure how much defoliation the crop can support in a certain phenological stage besides quantifying the loss of productivity at different defoliation levels (Bertoncello et al., 2011). Currently, studies investigating the different levels and stages of artificial defoliation in cassava are scarce.

This study was based on the work of Barrigossi, Zimmermann, and Lima (2002) in an attempt to quantify yield losses due to defoliation by different instars of Erinnyis ello caterpillars. Thus, using artificial defoliation, we can demonstrate that even a high

\footnotetext{
${ }^{*}$ Corresponding author:

Martios Ecco, Department of the course of Agronomy of the Pontifical Catholic University of Paraná, Toledo campus, Avenida da União, 500 85902-532, Toledo, Paraná, Brazil. Tel.: 85902-532. E-mail: amoraescatarino@gmail.com
} 
percentage of defoliation may not cause great damages to the crop, depending on the stage of crop development.

With information on the percentage of tolerated defoliation and the stage of cassava development that is less sensitive to defoliation, efficient and precise conditions can be determined to allow savings in the application of insecticides that are scarce for this crop. This will avoid damages to the productivity of roots and starch quantity due to the intensity of foliar consumption by defoliation pests.

Because of the influence of defoliation on production components, which ultimately affects quality and rentability, this study can provide information on plant behavior in relation to its capacity to support defoliation that occur due to pest attack or other factors that reduce leaf area. This study aims to evaluate the agronomic performance of cassava crop in relation to the timing and level of artificial defoliation, that is, what time and the level of defoliation that results in the highest yield losses and quality of cassava crop.

\section{MATERIAL AND METHODS}

The experiment was carried out under field conditions, in a rural property in the city of Guaíra, west of Parana, located between the coordinates $24^{\circ} 51^{\prime} \mathrm{S}, 54^{\circ} 12^{\prime} \mathrm{W}$ and with an altitude of 264 meters.

The soil is classified as a clayey Red Eutroferric Latosol and the local climate according to Köppen is Cfa type in which average annual temperatures range from 22 to $23^{\circ} \mathrm{C}$ and the annual rainfall varying between 882 and $2344 \mathrm{~mm}$.

Five levels of artificial defoliation (0, 25, 50, 75, and 100\% defoliation - Fig. 1) were evaluated in order to simulate attack by E. ello, the main pest of the crop, in five growing seasons. The levels of artificial defoliation were assessed 45, 90, 135, 180, and 225 days after planting (DAP).

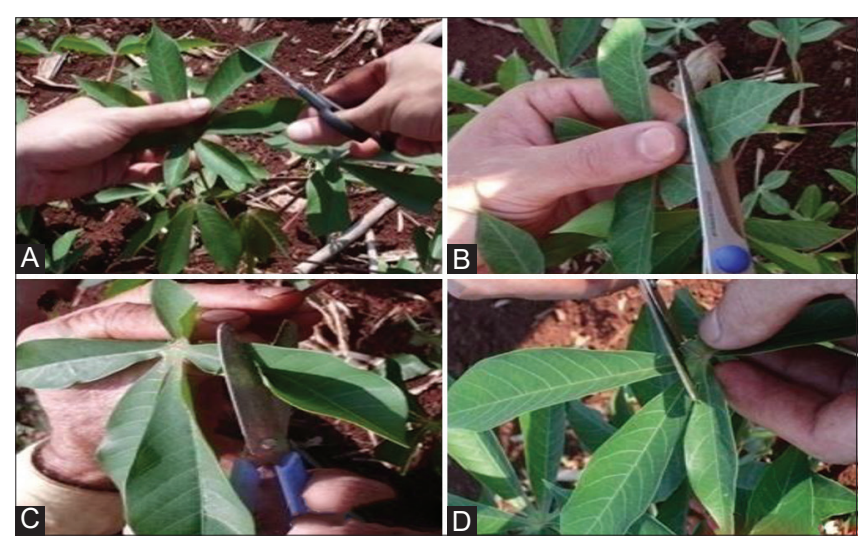

Fig 1. Moment of artificial defoliation: A) $25 \%$ defoliation, B) $50 \%$ defoliation, C) $75 \%$ defoliation and D) $100 \%$ defoliation.
The experimental design used was a randomized block design in a $5 \times 5$ factorial scheme, with five levels of defoliation, five stages of artificial defoliation, and three replicates, for a total of 25 treatments.

Before the experiment was implanted, the soil was sampled in two depths $(0-20 \mathrm{~m}$ and $0,21-0,40 \mathrm{~m})$ with a Dutch auger, to characterize the chemical attributes. The results were respectively: $\mathrm{pH}: 5,5$ and 5; $\mathrm{P}$ (20,5 and 11,7 $\left.\mathrm{mg} \mathrm{dm}^{-3}\right)$; $\mathrm{MO}$ (20,5 and 7,4 $\left.\mathrm{g} \mathrm{dm}^{-3}\right), \mathrm{K}, \mathrm{Ca}, \mathrm{Mg}, \mathrm{Al}, \mathrm{SB}, \mathrm{CTC}, \mathrm{H}+\mathrm{Al}(0,8$ and 0,$6 ; 7,9$ and 5,8;1,6 and 1,1;0,0 and 0,0;10,4 and 7,5; 14,6 and 11,$9 ; 4,3$ and $\left.4,4 \mathrm{cmol}_{\mathrm{c}} \mathrm{dm}^{-3}\right) ; \mathrm{V}=70,7$ and $63 \%$.

Subsequent to the soil analysis, it was carried out the tillage system by means of a disk plow followed by two harrowings. The planting was carried out at October second, of 2012 with a drill planter of the brand Planti Center model Bazuca 1, with regulation of cut of stalks approximately of $15 \mathrm{~cm}$, spacing between plants of $0,55 \mathrm{~m}$ and between lines of $0,65 \mathrm{~m}$, using the variety known as "cascudinha", considered as wild cassava due to the presence of hydrocyanic acid ( $\mathrm{HCN})$.

Each plot comprised an area of $20.8 \mathrm{~m}^{2}$ consisting of five lines $8 \mathrm{~m}$ in length, with around 14-15 stalks per line in the plot (72 plants); therefore, a total experimental area of $2268 \mathrm{~m}^{2}$ and a population of 27,972 plants per hectare was used. The useful area of the plot consisted of the second planting line, from which 10 plants were harvested, excluding two plants from each end of the line, which were the first and third line of the border.

At the time of the first defoliation, the incidence of first- and third-instar E. ello was determined by manually checking the plants. Leaves were defoliated with scissors in the relative proportions for each level, as previously mentioned, with the lobes of all leaves of the plant cut.

At the time of the final defoliation (225 DAP), morphological analyzes were performed, including determination of the aerial part height, stem diameter on the base, and number of leaves. Ten plants per plot were used for these measurements. The height was measured from the soil surface to the apical meristem with a measuring tape (scale in $\mathrm{cm}$ ) and the stem diameter was determined by means of a digital caliper at a height of approximately $5 \mathrm{~cm}$ from the soil surface.

The harvest was performed on July 24, 2013. The crop was in the so-called "physiological rest period" with all leaves falling naturally, and only the stem (branches) remaining. The second planting line was harvested because the first and the third lines were used as a border. The following parameters were evaluated: aerial weight, root weight, root 
length, root diameter, number of roots per plant, and amount of starch.

These parameters were evaluated in 10 plants in the same planting line. In these lines, initially the plants were pruned with a machete $0.30 \mathrm{~m}$ from the soil surface, and the stems (branches-leaves) were weighed in a scale with a capacity of $15 \mathrm{~kg}$. Afterwards, the plants were manually pulled out and left in the planting line, and the roots per plant were counted, root length was measured with a measurement tape (all the roots of the plant), and the diameter was determined with a digital caliper in the middle part of the plants. Once these measurements had been made, the roots were separated from the stems and weighed in the same scale used for the aerial part in the same order, that is, the aerial part of the plants according to the roots of the same plant.

To determine the cassava starch content, approximately $7 \mathrm{~kg}$ of roots were harvested at random in the useful plot then taken to a starch industry to measure the variable through the hydrostatic balance method, using a sample of $5 \mathrm{~kg}$ of tuberous roots (Rimoldi et al., 2003 apud Grosmann and Freitas, 1950). This measurement was performed at Indemil Brazil Starch industry located in the municipality of Guaíra.

The results of the production variables were tabulated and submitted to the analysis of variance at $5 \%$ of significance by the F Test, and the quantitative means submitted to regression test at $5 \%$ of probability using the SISVAR software 5.4 - System for analysis of variance (Ferreira, 2011).

\section{RESULTS AND DISCUSSION}

Analysis of variance of the regression presented a significant $F$ value $(p<0,05)$ for the isolated factors levels and stages of defoliation, and for the interaction between the factors of defoliation and the parameters: height, stem diameter, root diameter, root weight, and starch content. These results indicate that increasing the level of defoliation reduces the observed responses, and the intensity depends on the stage in which they occur.

Differences in plant size could be observed for all defoliation stages tested (Fig. 2A). Defoliation at 90 DAP resulted in the greatest loss of height, mainly at $100 \%$ defoliation. This may be because at this stage, the plant is redirecting the photoassimilates produced by the leaves to the growth of the aerial part, coinciding with its phenological cycle (Alves, 2006). When defoliation was performed at 180 and $225 \mathrm{DAP}$, plant size was not affected by the level of defoliation, because at these stages, the cassava plant did not invest in growth and most of the photoassimilates were directed to root growth. This is supported by the findings of Viecelli, Fillwock, and Suzin (2011); depending on the stage of development, the crop is generally tolerant to certain levels of defoliation, that is, some development stages exhibit a smaller reduction compared to the other stages.

Evaluation of the effect of defoliation level on plant height revealed significant differences in plant size for all defoliation levels tested compared with the control $(0 \%$ of defoliation). Defoliations exceeding 25\% were sufficient to reduce plant height in all stages of defoliation, mainly at $90 \mathrm{DAP}$, in which the plants had an average height of $1.63 \mathrm{~m}$ at the end of the cycle (Fig. 2B) showing a quadratic adjustment. Conversely, defoliations performed at 135, 180, and 225 DAP resulted in the lowest reduction in height, independent of the defoliation level.

For this variable in the cassava crop, in which the treatment where there was no defoliation and the same one in lesser intensity, resulted in a higher plant height, in which, as there was a greater defoliation intensity, the decrease in height was accentuated. According to Diniz Neto et al. (2012), this may be due to the presence of more leaves, making it possible to synthesize and assimilate a greater quantity of carbohydrates during the photosynthetic process.

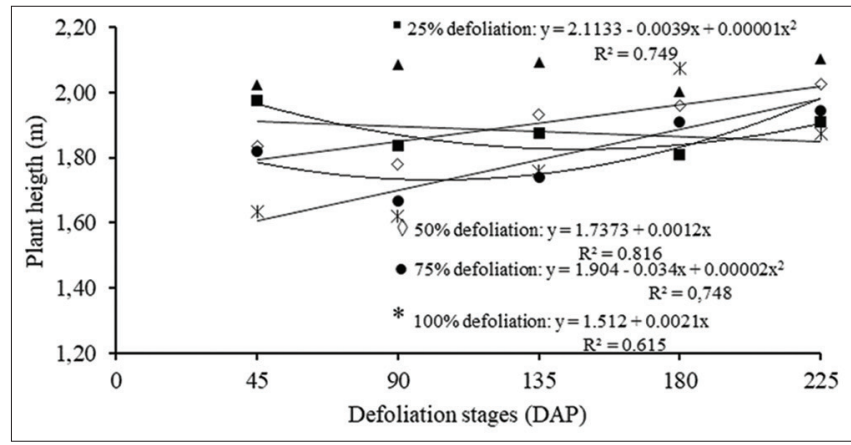

Fig 2 A. Average height of cassava plants cultivated in Guaíra - PR, crop 2012/2013, submitted to different stages of artificial defoliation.

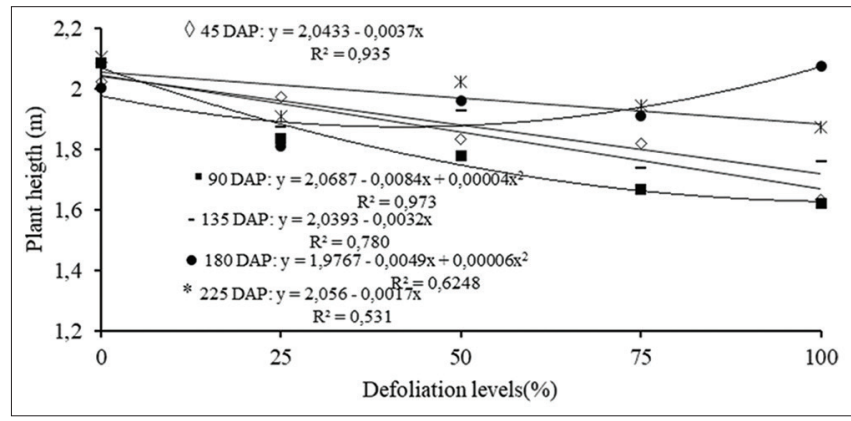

Fig 2 B. Average height of cassava plants cultivated in Guaíra - PR, crop 2012/2013, submitted to different levels of artificial defoliation. 
Analysis of stem diameter revealed differences in plants for all defoliation stages tested (Fig. 3A). Defoliation performed at $90 \mathrm{DAP}$, as observed for plant height, resulted in the greatest reduction in stem diameter, mainly with defoliations at $50 \%$ and above, with a reduction in the stem diameter of approximately $10.2 \%$ compared with the control. The same explanation for the reduction of aerial height at this stage is also valid, whereby the cassava plant is investing photoassimilates produced in the leaves into aerial growth (height and stem diameter) coinciding with its phenological cycle (Alves, 2006). Defoliations performed at 180 and 225 DAP were not affected by the different defoliation levels, as observed for the height parameter, based on the work of Viecelli, Fillwock, and Suzin (2011), as previously noted.

The importance of these two parameters (height and stem diameter) to the cassava crop is due to the use of part of the stem, or branch, as a propagation material. Therefore, the smaller the height and diameter, the smaller the number of stems that can be used as "seeds," and the smaller the amount of reserves accumulated in these stems that can be used by the seedling originated by the bud of the stem.

The behavior for stem diameter is similar, because at the beginning of growth for a particular plant species, biotic or abiotic factors that lead to defoliation will directly interfere with the growth measurements, such as stem diameter, leading to a performance that is contrary to that for aerial height, mainly when initially submitted to defoliation at higher intensities. These results confirm the importance of leaves for plant development and, consequently, for the formation of reserve organs such as fruits and tuberous roots. This is because the leaf has the highest photosynthetic rate, which can confer the largest stem diameter due to the quantity of photoassimilates stored during its cycle (Taiz and Zeiger, 2009).

The cassava stem diameter was reduced with all levels of defoliation (Fig. 3B). Defoliation at 50, 75, and 100\% influenced stem diameter the most; $75 \%$ defoliation performed at 90 DAP resulted in a stem diameter of $24.43 \mathrm{~mm}$.

Under the experimental conditions of this study, there was no significant effect on root length. The reduced height and stem diameter may limit the photoassimilates, which may physically limit the size of the reserve organs; however, it did not influence growth in length.

According to Aguiar (2003), the production of cassava in terms of root size and uniformity may be influenced by several factors; however, the non-alteration of cassava root length "cascudinha" variety may be due to two main reasons. First, it is a characteristic of the variety used in this study, for

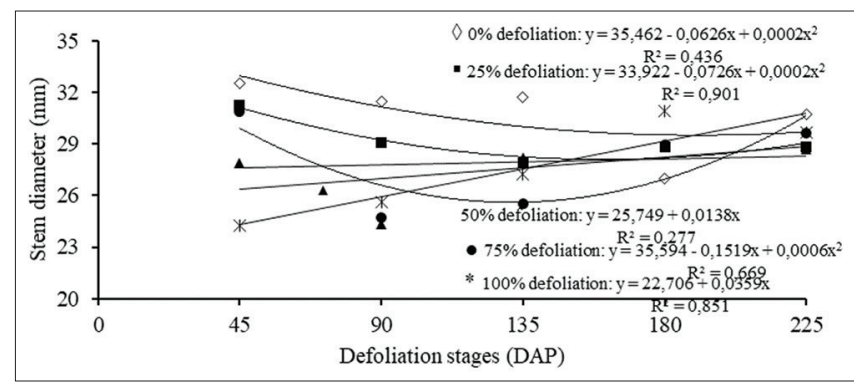

Fig 3 A. Average diameter of the stem base of cassava plants cultivated in Guaíra - PR, crop 2012/2013, submitted to different stages of artificial defoliation.

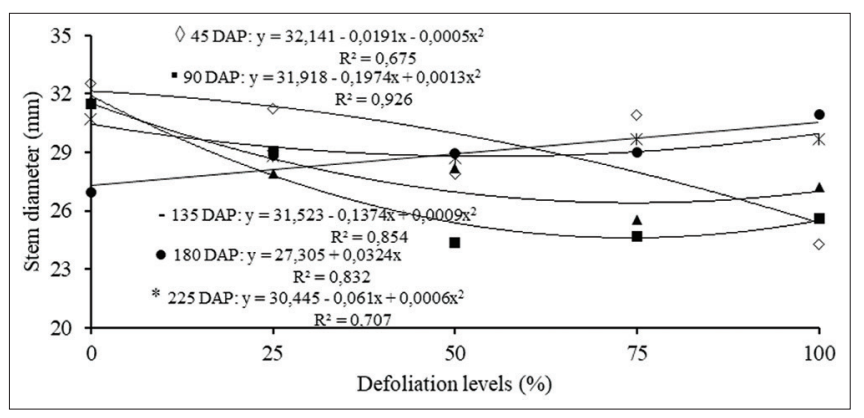

Fig 3 B. Average diameter of the stem base of cassava plants cultivated in Guaíra - PR, crop 2012/2013, submitted to different levels of artificial defoliation.

which there was no information about root length. Second, the population density adopted in this study, which was in accordance with the spacing $(0.65 \times 0.55 \mathrm{~m})$ used due to the regulation of the planter, provided a population of 27,972 plants per hectare. This is considered high for the crop, and the ideal would be approximately 15,000 plants per hectare.

The size of the root, namely the root length and diameter, was significant affected by the interaction between the levels and stages of defoliation. Defoliation at 135 DAP resulted in a smaller diameter when defoliation of 75 and $100 \%$ was performed (Fig. 4A). Notably, at this stage, the greatest loss in this parameter was observed; therefore, it is possible that during this period (135 DAP), the cassava plant is investing substantially in the growth and development of other structures.

Partial removal of cassava leaves (25 and 50\%) associated with high plant populations, may have contributed to the greater luminosity received by the remaining leaves, reflecting the greater accumulation of foliar dry matter without affecting the production of photoassimilates. The leaf is the main photosynthetic apparatus, and in addition to nutrients, accumulates organic compounds that will later be translocated to the other parts of the plant.

Regarding the levels of defoliation over developmental stages, a linear effect was observed; in the average where 
increased the defoliation level at $135 \mathrm{DAP}$ providing a reduction of $5.02 \%$ in the root diameter when compared to defoliation of $100 \%$ with the non-defoliated control (Fig. 4B). This behavior can be explained by the fact that the defoliations performed at 45 DAP occurred when the cassava plants were still differentiating the fibrous roots in tuberoses.

With defoliation at 95 DAP, most of photoassimilates were destined to form the aerial part and the tuberous roots, with no substantial translocation of photoassimilates to the roots, which had grown in diameter. This is in contrast to the period at $135 \mathrm{DAP}$, when there was marked translocation of photoassimilates to the storage organs. At 180 and 225 DAP, the levels of defoliation did not lead to a smaller root diameter, since root size may already be defined, with only the expenditure of reserves for the emission of new sources (Moreira, 2011).

A similar result was found by Nurmberg et al. (1999), who evaluated three levels of defoliation in two distinct stages of potato, and observed differences in the number of large tubers, especially with more drastic defoliations $(75 \%)$ resulting in a $20 \%$ reduction in large tubers, compared with the $25 \%$ level of defoliation; however, this was not significantly different from the non-defoliated control.

The number of cassava roots per plant is defined until about 120 days after planting (Alves, 2006). Defoliation before this period was not found to have a significant effect

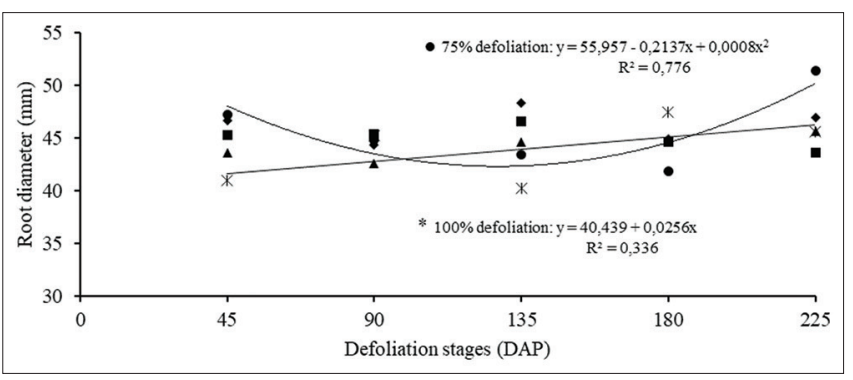

Fig 4 A. Average root diameter of cassava, cultivated in Guaíra - PR, crop 2012/2013, submitted to different stages of artificial defoliation.

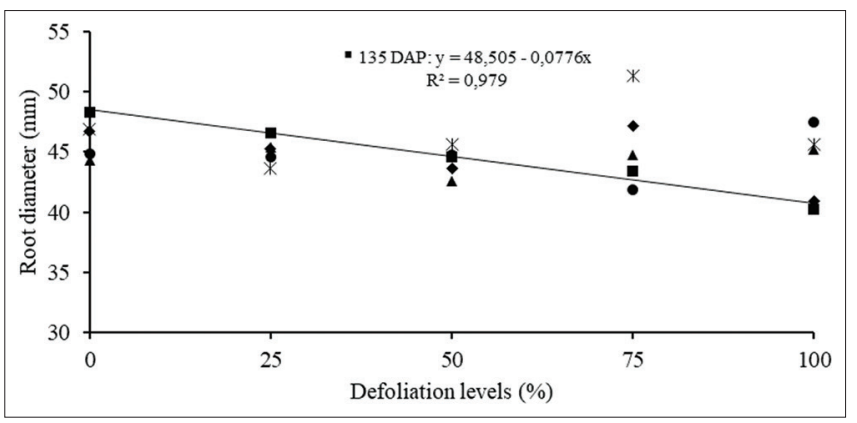

Fig 4 B. Average root diameter of cassava, cultivated in Guaíra - PR, crop 2012/2013, submitted to different levels of artificial defoliation. on the first cassava crop cycle. Therefore, as reported by Aguiar (2003), this may be related to a characteristic of the cultivar, since there was no problem related to the soil or cultural practices carried out in the crop or in the culture environment.

The different defoliation levels and development stages did not influence the aerial weight (AW), although stem height and diameter had a significant effect in relation to the treatments. This can be justified by the speed at which the aerial part recovers after defoliation, and the rhythm of root growth depends on a number of plant physiological mechanisms, such as the photosynthetic capacity of foliar tissue, reserves, plant height, and nutrient absorption (Sarmento et al., 2008). Another explanation for this effect in the AW is that during the physiological rest period of the cassava crop, reserves stored in the stem are translocated to the roots, providing weight reduction independently of the diameter or height, Therefore, with a larger diameter and height, the stem contains more reserves, which will cause roots to have a greater weight.

The regression analysis (Fig. 5A) revealed a quadratic effect for root weight according to the stages of artificial defoliation, indicating that cassava is sensitive to foliar losses in relation to the development period of the plant. Generally, when defoliation occurred at 135 DAP, according to the mathematical model, it resulted in greater root weight loss; that is, a yield of $33,874 \mathrm{~kg} \mathrm{ha}^{-1}$. This may help to calculate the action needed for the control of E. ello. The low root weight at $135 \mathrm{DAP}$ may have been due to the low level of translocation of photoassimilates, due to a reduction in the photosynthetically active area (number of leaves), thus reducing height, stem diameter and, consequently, the accumulation of reserves in the tuberous roots.

According to Aguiar (2003), the yield of cassava roots per unit area (hectare) is related to the size and not the number of roots, where the root mass is related to its diameter and length; a similar response to occurred in the present study investigating artificial defoliation of the crop.

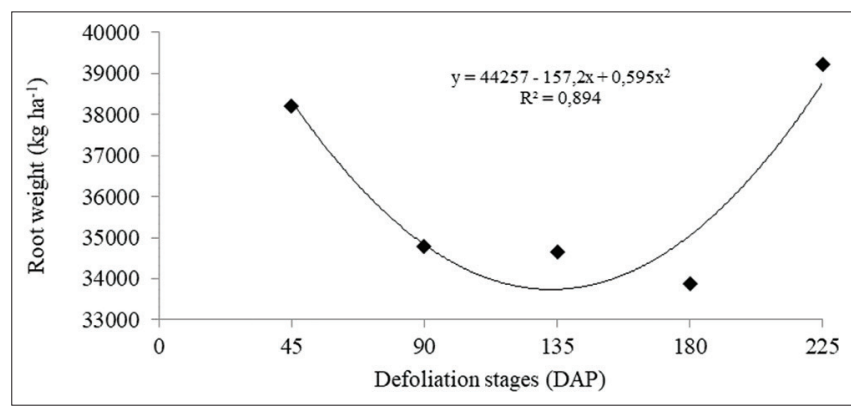

Fig 5 A. Root weight per cassava plant, cultivated in Guaíra - PR crop 2012/2013 submitted to different stages of artificial defoliation. 
In the present study, the greatest reduction in root mass occurred during the second fortnight of February. Aguiar et al. (2011) observed lower root mass when the cassava plants were pruned in April, a period near to the defoliation in this study that resulted in the lowest root weight. However, when pruning was performed from April to August, there was no significant change in the yield of cassava roots.

The regression analysis (Fig. 5B) presented a linear decreasing adjustment to the parameter of root weight according to the levels of artificial defoliation, inferring that different foliar losses were increasingly detrimental. The low value of this parameter with the of defoliation (75 and 100\%) may be due to the greater expense of the reserves stored in the tuberous roots for the reestablishment of the foliar area to re-produce photoassimilates for plant maintenance.

In contrast to cereals and other granular crops, tuberous roots in cassava develop along with the shoot (stem, petioles, and leaves). In this way, there is a simultaneous demand for assimilates for aerial and subterranean development, which compete during the plant life cycle (Soares, 2011). Therefore, according to Aguiar (2003) the yield of tuberous roots depends on the balance of carbohydrates available during plant development and the capacity of the roots to attract them and store them as starch.

Aguiar (2003) noted that changes in the translocation of photoassimilates to the roots in the first stages of development, when the tuberous roots begin to differentiate, may have large effects on its capacity as a drain, being able to compromise the flux of carbohydrates to the roots and, consequently, its production. In this study, it is likely that not even the translocation of reserves from the stem to the roots was sufficient to maintain the root weigh in equilibrium when compared to the non-defoliated plants. This can be explained by the reduced accumulation of photoassimilate reserves for the "mobilization in the phase of accumulation of starch" and by reduced level of photosynthesis following the removal of leaves.

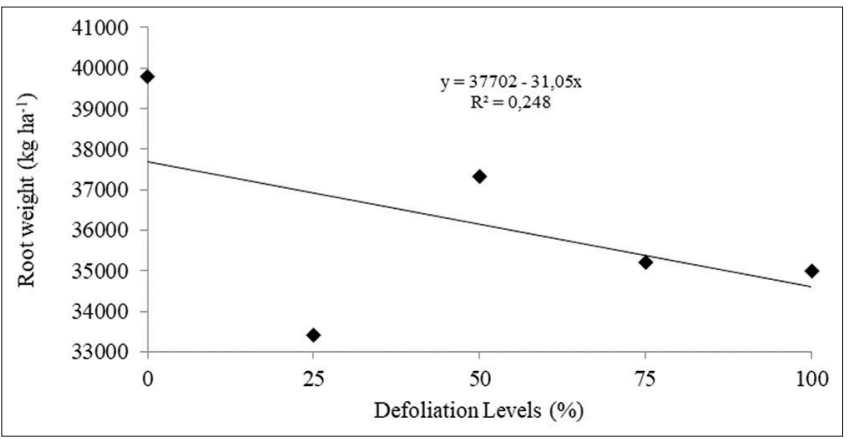

Fig 5 B. Root weight per cassava plant, cultivated in Guaíra - PR, crop 2012/2013 submitted to different levels of artificial defoliation.
Subsequently, after approximately 120 DAP, there is accelerated translocation of photoassimilates for the tuberous roots already formed, and for the stems and new leaves that being developed. Thus, this reduction in production is possibly due to competition between the vegetative parts; new leaves require carbohydrates that would have been used for the growth of tuberous roots. This competition is more accentuated as the levels of defoliation increase, leading to further reductions in root yield due to the lack of the photosynthetic apparatus to produce photoassimilates.

According to the regression analysis, starch amount was linearly adjusted (Fig. 6) for the influence of artificial defoliation levels. This indicates that the cassava responded to leaf losses according to the plant development period, mainly with high levels of defoliation (i.e. 75 and 100\%), which resulted in greater losses in the amount of starch stored in the tuberous roots. According to the mathematical model of the regression, $18.8 \%$ defoliation results in the highest amount of stored starch $(613 \mathrm{~g} / 5 \mathrm{~kg}$ of root); therefore, a defoliation by E. ello up to this level would be tolerated by the cassava crop, without causing economic losses.

Therefore, the reduced amount of stored starch was used for the formation of new shoots to compensate for the absence of leaves following defoliation, especially under greater levels of defoliations, or even following early defoliations, which directly interfered in the accumulation of starch in the tuberous roots, thus reducing storage.

Similar to cassava, potatoes produce organs specialized in storage (tubers); however, these monopolize the accumulation of processed products. Thus, despite being vegetatively propagated, starch losses do not equate to those of cassava when the aerial parts are lost, because the stems of cassava act as strong drains (Aguiar, 2003).

According to Aguiar et al. (2011), the cassava crop undergoes a period of physiological rest, which occurs

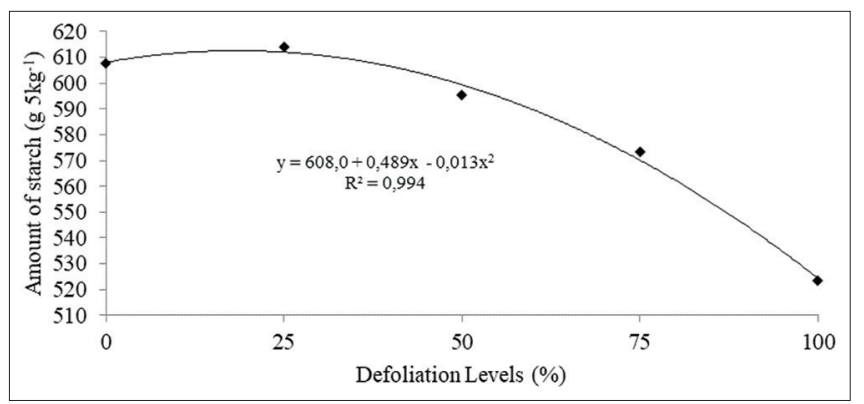

Fig 6. Amount of starch present in $5 \mathrm{~kg}$ of cassava roots, cultivated in Guaíra - PR, crop 2012/2013 submitted to different levels of artificial defoliation. 
during the coldest and driest months of the year, before the plant enters senescence. During this period, there is a large translocation of soluble sugars from the leaves to the stem and ramifications occurs. Later, these soluble carbohydrates stored in the stem are translocated to the roots, resulting in the development of tuberous roots. When these roots begin to differentiate, any alteration in the supply of carbohydrates to the roots during these initial stages of differentiation may damage the drain capacity, compromising the flux of carbohydrates and consequently their production (Aguiar, 2003; Aguiar et al., 2011).

\section{CONCLUSION}

The aerial weight was not influenced by the different levels and developmental stages of defoliation; therefore, this variable did not affect the stem height and diameter, as the root length was not influenced by the same treatments, and does not contribute to root weight.

Defoliations between 122 and 132 DAP resulted in greater damage to the root mass.

The most drastic defoliation levels, such as 75 and $100 \%$, caused the greatest losses in starch stored in the tuberous roots, regardless of the stage of defoliation.

\section{Author's contributions}

The experiment was carried out by Martios Ecco with the collaboration of the authors Augustinho Borsoi and Milciades Ariel Melgarejo Arrúa, who were always present in the accomplishment of all the conduction work of the experiment in the field. Antônio Carlos Torres da Costa and José Barbosa Duarte Junior whose orientation was indispensable within the postgraduate program in agronomy of the university.

\section{REFERENCES}

Aguiar, E. B. 2003. Produção e Qualidade de Raízes de Mandioca de Mesa (Manihot esculenta crantz) em Diferentes Densidades Populacionais e Épocas de Colheita. Dissertação (Mestrado em Tecnologia da Produção Agrícola). Intituto Agronômico de Campinas, Campinas.

Aguiar, E. B., S. J. Bicudo, F. Curcelli, P. G. Figueiredo and S. C. S. Cruz. 2011. Épocas de poda e produtividade da mandioca. Pesqui. Agropecu. Bras. 46: 1463-1470.

Alves, A. A. C. 2006. Fisiologia da mandioca. In: L. S. Souza, A. R. N.
Farias, P. L. P. Mattos and W. M. G. Fukuda (Eds.), Aspectos Socioeconômicos e Agronômicos da Mandioca. Embrapa Mandioca e Fruticultura Tropical, Cruz das Almas, BA.

Barrigossi, J. A. F., F. J. P. Zimmermann and P. S. C. Lima. 2002. Consumption rates and performance of Erinnyis ello L. on four cassava varieties. Neotrop. Entomol. 31: 429-433.

Bertoncello, T. F., S. L. Jr. Izidro, E. P. Melo, P. R. B. Fonseca and P. E. Degrande. 2011. Desfolha artificial simulando danos de pragas no cultivo de arroz de sequeiro de casa de vegetação. Rev. Acad. 9: 33-39.

Diniz Neto, M. A., I. F. Silva, B. L. M. Diniz, A. A. Pereira and A. R. Pereira. 2012. Componentes de produção de mamona em função de níveis de adubação nitrogenada e desfolha. Rev Ciênc. Agron. 43: 546-553.

Ferreira, D. F. 2011. SISVAR: Um Programa Para Análises e Ensino de Estatística. Revista Symposium, pp. 36-41.

Lima Junior, I. Santos, T.F. Bertoncello, E. P. Melo, P. E. Degrande and C. Kodama. 2010. Desfolha artificial simulando danos de pragas na cultura do girassol (Helianthus annuus L. Asteraceae). Rev. Ceres. 57: 23-27.

Nurmberg, P. L., C. A. B. Pinto, E. S. Lambert and C. b. Menezes. 1999. Simulação de danos causados por insetos na planta de batata por meio de desfolhamento artificial. Ciênc. Agrotecnol. 23: $468-472$.

Moreira, G. L. P. 2011. Intervalo Entre Podas em Mandioca. Dissertação (Mestrado em Ciências Agrárias Fitotecnia) Universidade Estadual do Sudoeste da Bahia, Vitória da Conquista.

Rimoldi, F., P. S. V. Filho, C. A. Scapim and M. C. G. Vidigal. 2003. Avaliação de cultivares de mandioca nos municípios de Maringá e de Rolândia no estado do Paraná. Acta Sci. Agron. 25: 459-465.

Sarmento, P., L. R. A. Rodrigues, S. M. B. Lugão, M. C. P. Cruz, F. P. Campos, M. E. Ferreira and R. F. Oliveira. 2008. Sistema radicular do Panicum maximum Jacq. cv.IPR-86 milênio adubado com nitrogênio e submetido à lotação rotacionada. Rev. Bras. Zootec. 37: 27-34.

Schmildt, E. R., J. A. T. Amaral, D. Pratissoli and E. F. Reis. 2010. Influência de desfolhas artificiais para simular perdas na produção do feijoeiro (Phaseolus vulgaris I. Cv. Xamego). Arquivos Inst. Biol. 77: 457-463.

Soares, M. R. S. 2011. Características de Variedades de Mandioca em Função de Épocas de Colheita. Dissertação (Programa de Pós-Graduação em Agronomia, área de Concentração em Fitotecnia), Universidade Estadual do Sudoeste da Conquista, Brazil.

Souza, V. Q., M. Nardino, G. O. Bonato, C. A. Bahry, B. O. Caron, P. D. Zimmer and D. Schmidt. 2013. Desfolha em diferentes estádios fenológicos sobre características agronômicas em trigo. Biosci. J. 29: 1905-1911.

Taiz, L. and Zeiger, E. 2009. Fisiologia Vegetal. $4^{\text {th }}$ ed. Artmed, Porto Alegre, p. 819.

Viecelli, C. A., J. M. Fillwock and V. Suzin. 2011. Efeito do desfolhamento das plantas na produtividade do milho. Rev. Bras. Tecnol. Apl. Ciênc. Agrár. 4: 179-190. 